\title{
UPAYA MENINGKATKAN MINAT DAN HASIL BELAJAR IPS SISWA KELAS VIII SMP NEGERI 28 BANJARMASIN MENGGUNAKAN METODE TEKA-TEKI SILANG
}

\author{
Siti Ridawati \\ Sekolah Menengah Pertama Negeri 28 Banjarmasin \\ E-mail : siti_ridawati678@gmail.com \\ Website : https://jurnal.uin-antasari.ac.id/index.php/ptkpend/index \\ Received: Juni 2019; Accepted: Agustus 2019; Published: Agustus 2019
}

\begin{abstract}
The crossword method can be used as a good and enjoyable learning strategy without losing the essence of ongoing learning. Research objectives to determine the increase in interest and student learning outcomes after the application of the cross-training Method in social studies learning in class VIII A of Banjarmasin State 28 SMP, with a total of 36 students. Data analysis techniques used are qualitative data analysis techniques which consist of data reduction, data presentation and conclusion drawing. In cycle I the average percentage of indicators of student interest in learning was $62 \%$. In the second cycle to $70 \%$ or an increase of $8 \%$. In cycle III, it increased by $18 \%$ to $88 \%$. Student learning outcomes percentage of students who achieved KKM scores in cycle I by $20 \%$ increased to $60 \%$ in cycle II.
\end{abstract}

Keywords: crossword puzzle; student learning interest; social studies learning

\begin{abstract}
ABSTRAK
Metode teka-teki silang dapat digunakan sebagai strategi pembelajaran yang baik dan menyenangkan tanpa kehilangan esensi belajar yang sedang berlangsung. Tujuan penelitian untuk mengetahui peningkatan minat dan hasil belajar siswa setelah penerapan metode tekateki silang pada pembelajaran IPS di kelas VIII A SMP Negeri 28 Banjarmasin, dengan jumlah siswa sebanyak 36 siswa. Teknik analisis data yang digunakan yaitu teknik analisis data kualitatif yang terdiri dari reduksi data, penyajian data dan penarikan kesimpulan. Pada siklus I rata-rata persentase indikator minat belajar siswa adalah 62\%. Pada siklus II menjadi $70 \%$ atau mengalami peningkatan sebesar $8 \%$. Pada siklus III mengalami peningkatan sebesar $18 \%$ sehingga menjadi $88 \%$. Hasil belajar siswa persentase siswa yang mencapai nilai KKM pada siklus I sebesar $20 \%$ meningkat menjadi $60 \%$ pada siklus II.
\end{abstract}

Kata Kunci: crossword puzzle; minat belajar siswa; pembelajaran IPS

\section{PENDAHULUAN}

Pendidikan merupakan proses untuk pengembangan diri manusia. Hal ini sesuai dengan amanat Undang-Undang No. 20 tahun 2003 tentang Sistem Pendidikan Nasional yang menyatakan bahwa pendidikan adalah usaha sadar dan terencana untuk mewujudkan suasana belajar dan proses pembelajaran agar peserta didik secara aktif mengembangkan potensi dirinya untuk memiliki kekuatan spiritual keagamaan, pengendalian diri, kepribadian, kecerdasan, akhlak mulia, serta keterampilan yang diperlukan dirinya, masyarakat, bangsa dan negara. Berdasarkan tujuan pendidikan dalam Undang-Undang tersebut, maka sudah seharusnya berbagai hal yang berkaitan dengan proses pendidikan dan pembelajaran mendapatkan perhatian yang lebih serius dalam upaya peningkatan sumber daya manusia yang berkualitas.

Menurut Isjoni (2010:14) menyatakan bahwa pembelajaran pada dasarnya merupakan upaya guru untuk membantu siswa melakukan suatu kegiatan belajar. Tujuan pembelajaran adalah terwujudnya efsiensi dan efektivitas 
kegiatan belajar yang dilakukan oleh siswa. Pihak-pihak yang terlibat dalam pembelajaran adalah guru dan siswa yang berinteraksi edukatif antara satu dengan yang lainnya.

Sedangkan Oemar Hamalik (2010: 57) mendefinisikan pembelajaran sebagai suatu kombinasi yang tersusun meliputi unsur-unsur manusiawi, material, fasilitas, perlengkapan, dan prosedur. Suatu kombinasi tersebut saling mempengaruhi untuk mencapai tujuan pembelajaran. Unsur manusia yang terlibat dalam pembelajaran terdiri dari siswa, guru, dan tenaga lainnya. Unsur material antara lain adalah bukubuku, papan tulis, dan kapur. Unsur fasilitas dan perlengkapan antara lain mencakup ruangan kelas dan perlengkapan visual. Unsur yang terakhir adalah prosedur. Prosedur dapat meliputi jadwal dan model penyampaian informasi.

Faktor dari dalam individu siswa juga sangat berpengaruh dalam proses belajar mengajar, seperti minat siswa dalam mengikuti proses belajar mengajar. Menumbuhkan minat belajar siswa merupakan salah satu faktor penting dalam kegiatan belajar mengajar. Tanpa adanya minat belajar, tidak mungkin siswa memiliki kemauan belajar dan dapat mencapai prestasi belajar yang optimal. Menurut Djaali (2007:121), minat adalah rasa lebih suka dan rasa keterikatan pada sesuatu hal atau aktivitas tanpa ada yang menyuruh. Pernyataan tersebut mengidentifikasikan bahwa orang yang berminat akan ada rasa tertarik. Tertarik dalam hal tersebut merupakan wujud dari rasa senang pada sesuatu.

Menurut Djamarah (2008:166), minat berarti kecenderungan yang menetap dan mengenang beberapa aktivitas. Seseorang yang berminat terhadap aktivitas akan memperhatikan aktivitas itu secara konsisten dengan rasa senang. Agus Sujanto (2004:92) berpendapat, bahwa minat sebagai sesuatu pemusatan perhatian yang tidak sengaja yang terlahir dengan penuh kemauannya dan tergantung dari bakat dan lingkungannya. Pernyataan tersebut menjelaskan bahwa minat merupakan pemusatan perhatian.

Metode pembelajaran teka-teki silang merupakan sistem pembelajaran yang memberikan kesempatan pada siswa untuk mengingat pelajaran yang berlangsung baik secara individu maupun dengan bekerja sama. Teka-teki silang dapat digunakan sebagai strategi pembelajaran yang baik dan menyenangkan tanpa meninggalkan esensi belajar yang sedang berlangsung (Hisyam Zaini, 2008: 71-72). Proses pembelajaran tidak harus berasal dari guru menuju siswa, tetapi antar siswa juga dapat saling mengajar. Pembelajaran oleh rekan sebaya ternyata lebih efektif dari pembelajaran oleh Guru (Agus Suprijono, 2012). Dengan demikian proses belajar dapat diperoleh dari bertukar pikiran antar siswa sehingga mereka dapat memahami pelajaran dan dapat mencapai keberhasilan dalam belajar.

SMP Negeri 28 Banjarmasin khususnya di kelas VIII A pada pelajaran IPS, siswa cenderung diam dan kurang aktif dalam mengikuti pembelajaran. Hal tersebut dimungkinkan karena Guru kurang bervariasi dalam penggunaan metode. Terlihat siswa terkadang merasa jenuh dengan proses pembelajaran yang dilaksanakan dan rendahnya minat siswa dalam mengikuti pelajaran yang tercermin dari sebagian siswa yang cenderung ramai dan tidak memperhatikan materi yang disampaikan oleh Guru. Hasil Belajar dikelas ini juga tergolong rendah karena hanya $63 \%$ dari jumlah siswa yang mencapai KKM sebesar 70. Apabila keadaan yang demikian terus terjadi, tujuan pendidikan akan semakin jauh untuk dicapai. Untuk mengatasi hal tersebut, perlu dikembangkan strategi pembelajaran yang lebih menarik yang dapat menambah minat belajar siswa untuk mengikuti proses pembelajaran tanpa adanya rasa keterpaksaan.

Menurut Mukminan, (2003), bahwa minat dapat mempengaruhi kualitas pencapaian hasil belajar siswa dalam bidang studi tertentu. Guru seyogyanya membangkitkan minat siswa untuk menguasai pengetahuan yang terkandung 
dalam bidang studinya dengan cara yang kurang lebih sama dengan membangun sikap positif.

Guru akan mencoba menerapkan metode teka-teki silang untuk meningkatkan minat dan hasil belajar siswa yang masih rendah. Tujuan penelitian adalah mengetahui peningkatan minat dan hasil belajar siswa setelah penerapan metode teka-teki silang pada pembelajaran IPS di kelas VIII A SMP Negeri 28 Banjarmasin.

\section{METODE PENELITIAN}

Penelitian ini menggunakan desain tindakan model Kemmis \& McTaggart terdiri dari empat komponen, yaitu: perencanaan, tindakan, observasi dan refleksi. Penelitian ini dilaksanakan di SMPN 28 Banjarmasin pada kelas VIII A Tahun Pelajaran 2017/2018 pada bulan Oktober-November 2017. Peneliti bertindak sebaga guru yang memberikan pembelajaran dengan metode teka-teki silang.

Instrumen penelitian 1) lembar obsevasi. Instrumen observasi digunakan oleh observer guna melakukan pengamatan minat belajar peserta didik di dalam kelas saat dilakukan tindakan pada proses pembelajaran. 2) dokumentasi. Data yang diperoleh dengan cara dokumentasi yaitu berupa foto yang menggambarkan aktivitas yang dilakukan siswa saat tindakan pada proses pembelajaran.

Teknik analisis data; 1) analisis data kualitatif, data yang berhasil dikumpulkan melalui observasi, wawancara dan catatan lapangan dianalisis dengan menggunakan metode analisis dari Miles dan Huberman (Sugiyono, 2009: 337-345). 2) Analisis data kuantitatif, digunakan untuk memberikan gambaran tentang peningkatan hasil belajar siswa. Hasil belajar siswa dihitung persentase ketuntasan menggunakan rumus dari Zainal Aqib, dkk (2009: 41) yaitu berikut ini.

$$
\mathrm{p}=\frac{\sum \text { siswa yang tuntas belajar }}{\Sigma \text { siswa }} \times 100 \%
$$

Keterangan:

$\mathrm{p}=$ persentase
Analisis data observasi minat belajar siswa dilakukan dengan langkah-langkah sebagai berikut:

1. Memberikan kriteria pemberian skor terhadap masing-masing diskriptor pada setiap indikator minat belajar siswa yang diamati.

2. Menjumlahkan skor untuk masingmasing indikator minat belajar siswa

3. Mempersentasekan skor minat belajar siswa pada setiap indikator yang diamati dengan menggunakan rumus:

$\mathrm{NP}=\frac{\mathrm{R}}{\mathrm{SM}} \times 100$

(Ngalim Purwanto, 2004: 102)

Keterangan:

$\mathrm{NP}=$ Nilai persen yang dicari atau diharapkan

$\mathrm{R}=$ Skor mentah yang diperoleh siswa

$\mathrm{SM}=$ Skor maskimum ideal dari tes yang bersangkutan

$100=$ Bilangan tetap

\section{Indikator Keberhasilan}

Penelitian ini dikatakan berhasil apabila mampu mencapai kriteria yang telah ditentukan. Zainal Aqib (2009: 41) menyatakan bahwa kriteria tingkat keberhasilan belajar siswa sebesar $75 \%$ sudah tergolong tinggi. Oleh karena itu, untuk mengukur keberhasilan tindakan dalam penelitian ini adalah sebagai berikut:

1. Penelitian ini dikatakan berhasil apabila rata-rata persentase indikator minat belajar siswa pada lembar observasi mencapai $75 \%$. Penelitian ini dikatakan berhasil apabila 75\% jumlah siswa kelas VIII A memiliki nilai minimal 70 pada mata pelajaran IPS. Hal ini berdasarkan kurikulum SMP Negeri 28 Banjarmasin mengenai Kriteria Ketuntasan Minimal (KKM) pada mata pelajaran IPS yaitu 70 .

\section{Siklus I}

Pengamatan terhadap minat belajar siswa dilakukan dari awal sampai dengan akhir pembelajaran. Hasil pengamatan terhadap minat belajar siswa pada siklus I menunjukkan belum tingginya minat belajar 
siswa dalam kegiatan pembelajaran dengan metode pembelajaran teka-teki silang. Berikut hasil observasi minat belajar siswa secara rinci.

Tabel 1. Hasil Observasi Minat Belajar Siswa Siklus I

\begin{tabular}{|c|c|c|c|c|c|}
\hline No & Aspek & Indikator & Persentase & $\begin{array}{l}\text { Rata-rata } \\
\text { Persentase } \\
\text { Indikator } \\
\end{array}$ & $\begin{array}{c}\text { Kriteria } \\
\text { Keberhasilan }\end{array}$ \\
\hline 1 & Perhatian & $\begin{array}{l}\text { Memperhatikan } \\
\text { guru saat proses } \\
\text { pembelajaran }\end{array}$ & $63 \%$ & & \\
\hline 2 & Ingin Tahu & $\begin{array}{l}\text { Menanyakan } \\
\text { materiyang } \\
\text { belum } \\
\text { dimengerti }\end{array}$ & $63 \%$ & $62 \%$ & $75 \%$ \\
\hline 3 & Keinginan & $\begin{array}{l}\text { Menjawab dan } \\
\text { merespon } \\
\text { petanyaan guru }\end{array}$ & $64 \%$ & & \\
\hline 4 & Rasa Senang & $\begin{array}{l}\text { Mengeriakan } \\
\text { tuggas dari guru }\end{array}$ & $63 \%$ & & \\
\hline
\end{tabular}

Perhitungan rata-rata persentase indikator minat belajar siswa siklus I di atas adalah sebagai berikut:

$$
\begin{aligned}
& \mathrm{NP}=\frac{\mathrm{K}}{\mathrm{SM}} \times 100 \% \\
& \mathrm{NP}=\frac{348}{560} \times 100 \%=62 \%
\end{aligned}
$$

Berdasarkan tabel 1 di atas, dapat diketahui bahwa pada siklus I rata-rata persentase indikator minat belajar siswa belum optimal atau belum mencapai kriteria keberhasilan yang ditetapkan yaitu $75 \%$ karena rata-rata persentase indikator minat belajar siswa pada siklus I baru mencapai 62\%. Adapun persentase tiap indikator minat belajar siswa pada siklus I yaitu perhatian $63 \%$, ingin tahu $63 \%$, keinginan $64 \%$ dan rasa senang $63 \%$. Untuk lebih jelasnya, dapat dilihat pada diagram di bawah ini.

Hasil kelompok dalam mengerjakan Teka-teki silang di bawah ini akan memberikan gambaran tentang hasil belajar siswa saat dilakukan tindakan penerapan metode pembelajaran Teka-teki silang. Nilai 70 adalah nilai KKM pada mata pelajaran IPS di SMP Negeri 28 Banjarmasin.

Hasil kelompok ini digunakan sebagai kontrol apakah peningkatan minat belajar siswa juga akan diikuti oleh peningkatan hasil belajar siswa. Tabel di bawah ini adalah hasil kelompok dalam mengerjakan teka-teki silang.

Tabel 2 Hasil Belajar Kelompok Siswa Siklus I

\begin{tabular}{ccccc}
\hline Nilai & $\begin{array}{c}\text { Jumlah } \\
\text { Nilai Siswa }\end{array}$ & $\begin{array}{c}\text { Jumlah } \\
\text { Siswa }\end{array}$ & Persentase & $\begin{array}{c}\text { Kriteria } \\
\text { Keberhasilan }\end{array}$ \\
\hline$\leq 70$ & 28 & 35 & $100 \%$ & $80 \%$ \\
\hline$\geq 70$ & 7 & 35 & $100 \%$ & $20 \%$ \\
\hline
\end{tabular}

Berdasarkan tabel 2 di atas, dapat diketahui bahwa jumlah siswa yang mencapai nilai KKM pada siklus I sebanyak 7 siswa dari 35 siswa atau baru mencapai persentase $20 \%$. Oleh karena itu belum berhasil mencapai kriteria keberhasilan yang ditetapkan yaitu $75 \%$. Sedangkan $80 \%$ siswa yang belum mencapai KKM ada sebanyak 28 siswa

\section{Refleksi}

Berdasarkan hasil obsevasi kegiatan pembelajaran dan catatan lapangan setelah pelaksanaan pembelajaran siklus I, dapat diperoleh kesimpulan bahwa pelaksanaan pembelajaran IPS dengan menerapkan metode pembelajaran teka-teki silang dalam siklus I cukup baik, akan tetapi kurang obtimal dalam penerapan metode teka-teki silang. Penguasaan kelas masih kurang sehingga banyak siswa yang berbuat keramaian di kelas dan dibiarkan saja.

Pada awal sampai pertengahan proses pembelajaran, perhatian siswa belum sepenuhnya terpusat pada materi pelajaran. Siswa masih belum paham dengan model pembelajaran yang diterapkan. Antusiasme siswa masih kurang. Penerapan metode pembelajaran teka-teki silang pada siklus I belum sepenuhnya dapat dilaksanakan secara optimal. Berdasarkan hasil pengamatan, rata- rata persentase indikator minat belajar siswa pada siklus I belum mencapai kriteria keberhasilan yang telah ditetapkan yaitu sebesar $75 \%$. Rata-rata persentase indikator minat belajar siswa pada siklus I adalah sebesar $62 \%$.

Berdasarkan data-data dan kendalakendala di atas, maka upaya meningkatkan minat belajar siswa dalam pembelajaran IPS dengan menggunakan metode pembelajaran teka-teki silang di kelas VIII A SMP Negeri 
28 Banjarmasin pada siklus I dapat dikatakan belum berhasil. Rata-rata indikator minat belajar siswa pada siklus I adalah $62 \%$ sehingga belum mencapai kriteria keberhasilan tindakan yang telah ditetapkan yaitu 75\%. Selain itu, persentase siswa kelas VIII A yang mencapai nilai KKM baru ada sebesar 20\%. Padahal kriteria keberhasilan yang harus dicapai adalah $75 \%$. Untuk itu perlu disusun rencana tindakan yang diperbaiki, rencana tindakan yang baru, ataupun yang dimodifikasi dari siklus sebelumnya pada siklus II agar mencapai kriteria keberhasilan tindakan.

\section{Siklus II}

Pengamatan atau observasi terhadap kegiatan guru pada siklus II dapat dikatakan belum optimal dan kurang sesuai dengan rencana tindakan penerapan metode pembelajran Teka-teki silang dengan lebih baik. Dalam memberikan penjelasan mengenai materi yang disertai dengan tanya jawab masih belum obtimal. Pengelolaan kelas yang dilakukan dalam siklus II belum menunjukkan perubahan yang berarti. Guru menegur siswa yang ramai dan membuat keributan di kelas. Penekanan dalam mengklarifikasi dan menyimpulkan materi pelajaran bersama siswa kurang.

Selanjutnya, hasil pengamatan terhadap siswa pada siklus II ini adalah siswa terlihat bosan dalam mengikuti kegiatan pada awal pembelajaran. Pada kegiatan akhir, guru mengajak siswa untuk menyimpulkan materi pelajaran. Akan tetapi, pada akhirnya guru yang memberikan kesimpulan karena siswa masih belum ada yang berani menyimpukan materi pelajaran.

Secara umum pengamatan terhadap minat belajar siswa dalam mengikuti kegiatan pembelajaran dapat dikatakan mengalami peningkatan dari siklus I. Akan tetapi rata-rata persentase indicator minat belajar siswa pada siklus II belum mencapai kriteria keberhasilan yang telah ditetapkan. Hal tersebut dibuktikan pada tabel di bawah ini.
Tabel 3. Hasil Observasi Minat Belajar Siswa Siklus II

\begin{tabular}{cccccc}
\hline No & Aspek & Indikator & Persentase & $\begin{array}{c}\text { Rata-rata } \\
\text { Persentase } \\
\text { Indikator }\end{array}$ & $\begin{array}{l}\text { Kriteria } \\
\text { Keberhasilan }\end{array}$ \\
\hline 1 & Perhatian & $\begin{array}{l}\text { Memperhatikan } \\
\text { guru saat proses } \\
\text { pembelajaran }\end{array}$ & $62 \%$ & & \\
\hline 2 & Ingin Tahu & $\begin{array}{l}\text { Menanyakan } \\
\text { materi yang } \\
\text { belum dimengerti }\end{array}$ & $76 \%$ & & \\
& & & & \\
\hline 3 & Keinginan & $\begin{array}{l}\text { Menjawab dan } \\
\text { Merespon } \\
\text { pertanyaan guru }\end{array}$ & $84 \%$ & $70 \%$ & $75 \%$ \\
\hline 4 & $\begin{array}{l}\text { Rasa } \\
\text { Senang }\end{array}$ & $\begin{array}{l}\text { Mengerjakan } \\
\text { tugas dari guru }\end{array}$ & $61 \%$ & & \\
\hline
\end{tabular}

Perhitungan rata-rata persentase indikator minat belajar siswa siklus II di atas adalah sebagai berikut:

$$
\begin{aligned}
& \mathrm{NP}=\frac{\mathrm{K}}{\mathrm{SM}} \times 100 \% \\
& \mathrm{NP}=\frac{394}{560} \times 100 \%=70 \%
\end{aligned}
$$

Berdasarkan tabel 5 di atas, dapat diketahui bahwa pada siklus II rata-rata persentase indikator minat belajar siswa belum optimal atau belum mencapai kriteria keberhasilan yang ditetapkan yaitu $75 \%$ karena rata-rata persentase indikator minat belajar siswa pada siklus II baru mencapai $70 \%$. Adapun persentase tiap indikator minat belajar siswa pada siklus I yaitu perhatian $62 \%$, ingin tahu $76 \%$, keinginan $84 \%$ dan rasa senang $61 \%$.

Hasil belajar kelompok siswa setelah diterapkannya metode pembelajaran Tekateki silang ditambahkan dengan gambar pada siklus II.

Tabel 4 Hasil Belajar Kelompok Siswa Siklus II

\begin{tabular}{ccccc}
\hline Nilai & $\begin{array}{c}\text { Jumlah } \\
\text { Nilai Siswa }\end{array}$ & $\begin{array}{c}\text { Jumlah } \\
\text { Siswa }\end{array}$ & Persentase & $\begin{array}{c}\text { Kriteria } \\
\text { Keberhasilan }\end{array}$ \\
\hline$\leq 70$ & 14 & 35 & $100 \%$ & $40 \%$ \\
\hline$\geq 70$ & 21 & 35 & $100 \%$ & $60 \%$ \\
\hline
\end{tabular}

Jumlah siswa yang mencapai nilai KKM pada siklus II sebanyak 21 siswa dari 35 siswa atau baru mencapai persentase $60 \%$. Oleh karena itu belum berhasil mencapai kriteria keberhasilan yang ditetapkan yaitu $75 \%$. Sedangkan $40 \%$ siswa yang belum mencapai KKM ada sebanyak 14 siswa. 


\section{Refleksi}

Berdasarkan hasil obsevasi kegiatan pembelajaran dan catatan lapangan setelah pelaksanaan pembelajaran siklus II, dapat diperoleh kesimpulan bahwa upaya peningkatan minat belajar siswa dengan metode pembelajaran Teka-teki silang lebih baik dari siklus I. Akan tetapi, guru masih kurang optimal dalam penyampaian materi di awal pembelajaran, dalam memberikan motivasi kepada siswa masih belum optimal.

Pengaruh penerapan metode pembelajaran teka-teki silang terhadap peningkatan minat belajar siswa dalam pelaksanaan pembelajaran IPS sudah lebih baik dibandingkan siklus I. Siswa mulai menunjukan adanya minat belajar IPS dengan baik. Siswa yang tadinya jarang membaca menjadi aktif membaca materi yang diberikan oleh huru. Terlihat mereka lebih antusias dalam mengikuti pelajaran.

Hasil refleksi siklus II ini adalah ratarata persentase indikator minat belajar siswa pada siklus II masih kurang atau belum mencapai kriteria keberhasilan yang ditetapkan yaitu $75 \%$ karena baru mencapai $70 \%$. Selain itu, persentase siswa yang mencapai nilai KKM belum mencapai $75 \%$ sesuai dengan kriteria keberhasilan yang telah ditetapkan. Persentase siswa yang mencapai nilai KKM pada siklus II adalah sebesar $60 \%$.

Beberapa tindakan yang mengakibatkan kegagalan pada siklus II ini adalah pengelolaan kelas belum sepenuhnya berhasil; beberapa siswa masih ramai pada saat pembelajaran di kelas, terutama siswa laki-laki; peningkatan minat belajar siswa melalui penggunaan gambar belum optimal dan hanya sedikit siswa yang berani bertanya dan menanggapi pertanyaan dari guru.

Berdasarkan data-data di atas dan dengan melihat masih ada kendala-kendala yang dihadapi pada saat penerapan metode pembelajaran teka-teki silang di kelas VIII A pada siklus II, maka secara umum dapat dikatakan bahwa upaya perbaikan yang dilakukan di siklus II belum berhasil. Untuk itu perlu disusun rencana tindakan yang diperbaiki, rencana tindakan yang baru, ataupun yang dimodifikasi dari siklus sebelumnya pada siklus III agar mencapai kriteria keberhasilan tindakan.

\section{Siklus III}

Pengamatan terhadap kegiatan guru pada siklus III menunjukkan bahwa guru sudah dapat melakukan kegiatan pembelajaran dengan baik dalam penerapan metode teka-teki silang. Pengelolaan kelas yang dilakukan oleh Guru dalam siklus III ini jauh lebih baik dibandingkan siklus II. Guru mampu menjelaskan dan mengorganisasikan pembelajaran aktif dengan metode teka-teki silang secara lebih baik. Selain itu, guru juga memberikan dorongan seperti memberikan motivasi kepada siswa untuk menumbuhkan minat belajar siswa di dalam kelas.

Siswa terlihat lebih berminat dalam proses pembelajaran di dalam kelas. Siswa terlihat sangat bersemangat. Siswa juga lebih berani dalam menyampaikan ide maupun pendapatnya dalam menjawab pertanyaan yang diberikan. Selain itu siswa juga lebih berani bertanya. Siswa yang pada siklus sebelumnya terlihat pasif juga sudah mulai aktif. Pada kegiatan akhir, siswa berpartisipasi aktif dengan cara menyimpulkan materi pelajaran bersama dengan guru hal ini menunjukan bahwa minat belajar sisiwa sudah baik sesuai dengan indikator minar belajar yang diukur.

Secara umum pengamatan terhadap minat belajar siswa dalam mengikuti kegiatan pembelajaran pada siklus III terlihat mengalami peningkatan dari siklus II. Peningkatan dari siklus II tersebut mengakibatkan rata-rata persentase minat belajar siswa pada siklus III mencapai kriteria keberhasilan tindakan yang telah ditetapkan. Hal tersebut terlihat pada tabel di bawah ini 
Jurnal PTK \& Pendidikan

Vol. 5, No. 1, Hal (37-47)

Tabel 5. Hasil Observasi Minat Belajar Siswa Siklus III

\begin{tabular}{cccccc}
\hline No & Aspek & Indikator & Persentase & $\begin{array}{c}\text { Rata-rata } \\
\text { Persentase } \\
\text { Indikator }\end{array}$ & $\begin{array}{c}\text { Kriteria } \\
\text { Keberhasilan }\end{array}$ \\
\hline 1 & Perhatian & $\begin{array}{l}\text { Memperhatikan } \\
\text { guru saat proses } \\
\text { pembelajaran }\end{array}$ & $87 \%$ & & \\
\hline 2 & Ingin Tahu & $\begin{array}{l}\text { Menanyakan } \\
\text { materi yang } \\
\text { belum dimengerti }\end{array}$ & $86 \%$ & & \\
\hline 3 & Keinginan & $\begin{array}{l}\text { Menjawab dan } \\
\text { merespon } \\
\text { petanyaan guru }\end{array}$ & $90 \%$ & $88 \%$ & $75 \%$ \\
in & Rasa Senang & $\begin{array}{l}\text { Mengerjakan tugas } \\
\text { dari guru }\end{array}$ & $92 \%$ & & \\
\hline 4
\end{tabular}

atas adalah sebagai berikut:

$$
\begin{aligned}
& \mathrm{NP}=\frac{\mathrm{K}}{\mathrm{SM}} \times 100 \% \\
& \mathrm{NP}=\frac{496}{560} \times 100 \%=88 \%
\end{aligned}
$$

Berdasarkan tabel 5 di atas, dapat diketahui bahwa pada siklus III rata-rata persentase indikator minat belajar siswa sudah optimal atau sudah mencapai kriteria keberhasilan yang ditetapkan yaitu $75 \%$ karena rata-rata persentase indikator minat belajar siswa pada siklus III mencapai $88 \%$. Adapun persentase tiap indikator minat belajar siswa pada siklus I yaitu perhatian $87 \%$, ingin tahu $86 \%$, keinginan $90 \%$ dan rasa senang $92 \%$. Untuk lebih jelasnya, dapat dilihat pada diagram di bawah ini.

Hasil belajar kelompok siswa setelah diterapkannya metode pembelajaran Tekateki silang. Tabel di bawah ini akan memberikan gambaran tentang peningkatan hasil belajar siswa dari siklus II ke siklus III. Hasil belajar ini digunakan sebagai kontrol apakah peningkatan minat belajar siswa juga akan diikuti oleh peningkatan hasil belajar siswa. siklus II.

Tabel 6. Hasil Belajar Kelompok Siswa Siklus III

\begin{tabular}{ccccc}
\hline Nilai & $\begin{array}{c}\text { Jumlah } \\
\text { Nilai Siswa }\end{array}$ & $\begin{array}{c}\text { Jumlah } \\
\text { Siswa }\end{array}$ & Persentase & $\begin{array}{c}\text { Kriteria } \\
\text { Keberhasilan }\end{array}$ \\
\hline$\leq 70$ & 7 & 35 & $100 \%$ & $20 \%$ \\
\hline$\geq 70$ & 28 & 35 & $100 \%$ & $80 \%$ \\
\hline
\end{tabular}

Berdasarkan tabel 6 dapat diketahui bahwa jumlah siswa yang mencapai nilai KKM pada siklus III sebanyak 28 siswa dari 35 siswa atau baru mencapai persentase $80 \%$. Oleh karena itu belum berhasil mencapai kriteria keberhasilan yang ditetapkan yaitu $75 \%$. Sedangkan $20 \%$ siswa yang belum mencapai KKM ada sebanyak 7 siswa.

\section{Refleksi}

Berdasarkan hasil obsevasi kegiatan pembelajaran dan catatan lapangan setelah pelaksanaan pembelajaran siklus III, dapat disimpulkan bahwa terdapat peningkatan minat belajar siswa yang jauh lebih baik dari siklus-siklus sebelumnya. Pada siklus III, pengaruh penerapan metode pembelajaran Teka-teki silang terhadap peningkatan minat belajar siswa dalam pelaksanaan pembelajaran IPS sangat besar.

Siswa terlihat lebih berminat dalam mengikuti proses pembelajaran di kelas. Siswa juga lebih berani dalam menyampaikan ide maupun pendapatnya dalam menjawab pertanyaan Guru. Selain itu siswa juga lebih berani bertanya, siswa yang pada siklus sebelumnya terlihat pasif juga sudah mulai aktif berpartisipasi di kelas.

Guru sudah dapat melakukan kegiatan pembelajaran dengan baik. Pengelolaan kelas yang dilakukan dalam siklus III ini jauh lebih baik dibandingkan siklus II. Guru mampu menjelaskan dan mengorganisasikan pembelajaran aktif dengan metode teka-teki silang secara lebih baik. Selain itu juga sudah memberikan motivasi kepada siswa agar lebih berperan aktif di dalam kelas.

Respon siswa juga sangat baik. Siswa terlihat senang dan sangat bersemangat. Suasana kelas menjadi menyenangkandan kondusif. Minat siswa dalam mengikuti proses pembelajaran sudah terlihat dalam setiap tahap pembelajaran serta banyak dari siswa yang sudah fokus dengan pembelajaran yang dilakukan.

Proses pembelajaran di kelas berlangsung dinamis. Hal tersebut ditandai dengan minat belajar siswa dalam menyampaikan pertanyaan dan memberi tanggapan terhadap pertanyaan Guru sehingga suasana lebih hidup.

Pada siklus III rata-rata persentase indikator minat belajar siswa sudah optimal atau sudah mencapai kriteria keberhasilan 
yang ditetapkan yaitu 75\% karena rata-rata persentase indikator minat belajar siswa pada siklus III mencapai $88 \%$. Selain itu, persentase siswa yang mencapai nilai $\leq 70$ pada siklus ini sudah mencapai kriteria keberhasilan yang telah ditetapkan yaitu $75 \%$ bahkan melebihi.

Persentase siswa kelas VIII A yang berhasil mencapai nilai $\leq 70$ adalah $88 \%$. Selain itu, persentase siswa yang mencapai nilai $\leq 70$ pada siklus ini sudah mencapai kriteria keberhasilan yang telah ditetapkan yaitu $75 \%$ bahkan melebihi. Persentase siswa kelas VIII A yang berhasil mencapai nilai $\leq 70$ adalah $80 \%$. Hal ini didukung dengan pengakuan sebagian besar siswa yang mengaku lebih menyenangkan dan mudah memahami materi setelah diterapkannya metode pembelajaran Tekateki silang.

Berdasarkan hasil pengamatan dan diskusi yang dilakukan antara guru dengan siswa pada siklus III, maka secara umum upaya perbaikan yang dilakukan dapat dikatakan berhasil atau dapat disimpulkan bahwa hipotesis tindakan seperti yang telah dijelaskan pada BAB II terbukti atau diterima

\section{Pembahasan}

Penelitian ini merupakan jenis Penelitian Tindakan Kelas (Classroom Action Research). Penelitian Tindakan Kelas (PTK) dapat diartikan sebagai upaya atau tindakan yang dilakukan oleh guru atau guru untuk memecahkan masalah pembelajaran melalui kegiatan penelitian. Penelitian tindakan kelas ini dilaksanakan di SMP Negeri 28 Banjarmasin yang dilakukan sebanyak tiga siklus. Penelitian ini bertujuan untuk mengetahui peningkatan minat belajar siswa setelah penerapan metode pembelajaran Teka-teki silang pada pembelajaran IPS di kelas VIII A SMP Negeri 28 Banjarmasin.

Hasil analisis pada siklus I sampai dengan siklus III menunjukkan bahwa penerapan metode pembelajaran Teka-teki silang dapat meningkatkan minat belajar siswa dalam pembelajaran IPS di kelas VIII A SMP Negeri 28 Banjarmasin. Hal ini didukung dengan data rata-rata persentase indikator minat belajar siswa yang meningkat tiap siklusnya sampai berhasil mencapai kriteria keberhasilan yang telah ditetapkan pada siklus III.

Pada siklus I, guru kurang dapat melakukan kegiatan pembelajaran dengan baik. Guru kurang mampu menjelaskan dan mengorganisasikan penerapan metode pembelajaran Teka-teki silang. Guru belum dapat mengontrol kelas dengan baik. Pada awal pembelajaran, guru tidak melakukan apersepi. Guru pun tidak memberikan penguatan dan menyimpulkan materi pelajaran di akhir pembelajaran. Upaya meningkatkan minat belajar siswa dengan menerapkan metode pembelajaran Teka-teki silang di kelas VIII A SMP Negeri 28 Banjarmasin pada siklus I belum berhasil dengan baik. Hal tersebut dibuktikan dengan rata-rata persentase indikator minat belajar siswa pada lembar observasi baru mencapai $62 \%$, sedangkan kriteria keberhasilan tindakan yang telah ditetapkan adalah $75 \%$. Selain itu, dilihat dari hasi belajar kelompok siswa yang mencapai nilai KKM masih dibawah krtiteria keberhasilan yang ditetapkan yaitu $75 \%$. Siswa yang mencapai KKM pada siklus I sebanyak $20 \%$ atau 7 siswa. Siswa yang belum mencapai KKM pada siklus I sebanyak $80 \%$ atau 28 siswa.

Beberapa kelemahan atau kendala yang mengakibatkan kegagalan tersebut adalah sebagai berikut: 1) Guru kurang mampu untuk menjelaskan kegiatan pembelajaran dengan metode teka-teki silang; 2) Guru kurang memotivasi siswa agar berperan aktif mengikuti kegiatan pembelajaran; 3) Guru belum dapat memanfaatkan waktu secara optimal dan efektif pada saat pembelajaran di kelas berlangsung; 4) Guru kurang tegas menegur siswa yang membuat keributan di kelas; 5) Tidak meratanya pendampingan Guru saat diskusi berlangsung; 6) Rata-rata persentase indikator minat belajar belum mencapai kriteria keberhasilan tindakan karena baru mencapai $62 \%$.

Berdasarkan permasalahan atau kelemahan yang muncul pada siklus I, maka 
guru membuat tambahan perencanaan pada pembelajaran siklus II yaitu Peningkatan kemampuan dalam menjelaskan kegiatan pembelajaran kepada siswa. Peningkatan kemampuan dalam mekanisme pengajaran dengan metode teka-teki silang, Peningkatan motivasi siswa agar berperan aktif dan bersemangat dalam mengikuti kegiatan pembelajaran melalui penggunaan gambar

Dalam lembar kertas teka-teki silang, pemanfaatan waktu secara optimal dan efektif pada saat pembelajaran di kelas berlangsung, Peningkatan ketegasan dalam menghadapi siswa yang ramai atau membuat keributan di kelas dan Peningkatan pendampingan siswa saat diskusi berlangsung.

Selanjutnya, pada proses pembelajaran siklus II, guru masih dikatakan belum optimal dalam melakukan kegiatannya. Selain itu pelaksanaan tindakannya kurang sesuai dengan rencana tindakan walaupun guru mampu menjelaskan dan mengorganisasikan pembelajaran dengan metode teka-teki silang dengan lebih baik. Pengelolaan kelas yang dilakukan oleh guru dalam siklus II belum menunjukkan perubahan yang berarti. Pengelolaan kelas belum sepenuhnya berhasil, masih ada beberapa siswa yang ramai pada saat pembelajaran di kelas, terutama siswa laki-laki. Hanya sedikit siswa yang berani bertanya dan menanggapi pertanyaan dari guru.

Pada awal pembelajaran siklus II siswa tampak bosan dalam mengikuti kegiatan pembelajaran hal ini menunjukan bahwa minat belajar siswa masih rendah dalam mengikuti pembelajaran IPS. Pada kegiatan akhir, guru mengajak siswa bersama-sama untuk menyimpulkan materi pelajaran. Akan tetapi, pada akhirnya guru yang memberikan kesimpulan karena siswa belum ada yang berani mengemukakan pendapatnya untuk menyimpulkan.

Upaya meningkatkan minat belajar siswa dengan menerapkan metode pembelajaran teka-teki silang di kelas VIII A SMP Negeri 28 Banjarmasin pada siklus II masih belum berhasil mencapai kriteria keberhasilan yang telah ditetapkan yaitu $75 \%$ walaupun terdapat peningkatan persentase dari siklus I. Hal tersebut dibuktikan dengan rata-rata persentase indikator minat belajar siswa yang meningkat sebesar $8 \%$ dari siklus I menjadi $70 \%$. Peningkatan persentase indikator minat juga berpengaruh pada peningkatan persentase indikator hasil belajar kelompok siswa yang meningkat sebesar $40 \%$ dari siklus I menjadi $60 \%$ walaupun hasilnya masih dibawah krtiteria keberhasilan yang ditetapkan yaitu $75 \%$.

Peningkatan-peningkatan tersebut terjadi setelah diterapkannya metode pembelajaran teka-teki silang dengan ditambah gambar dalam lembar teka- teki silang sebagai motivasi dan untuk menarik perhatian siswa. Selain itu juga, karena guru sudah mampu menjelaskan dan mengorganisasikan pembelajaran dengan metode teka-teki silang dengan lebih baik dari siklus I. Beberapa tindakan yang mengakibatkan kegagalan pada siklus II adalah sebagai berikut: 1) Pengelolaan kelas belum sepenuhnya berhasil; 2) Beberapa siswa masih ramai pada saat pembelajaran di kelas, terutama siswa laki-laki; 3) Peningkatan motivasi siswa melalui penggunaan gambar belum optimal; 4) Hanya sedikit siswa yang berani bertanya dan menanggapi pertanyaan dari guru.

Berdasarkan permasalahan atau kelemahan yang muncul pada siklus II, maka guru membuat tambahan perencanaan pada pembelajaran siklus III yaitu mengelola kelas harus lebih baik dengan ketegasan, memberikan motivasi kepada siswa secara optimal dengan menggunakan gambar yang lebih menarik.

Pada akhirnya, pengamatan terhadap kegiatan guru pada siklus III menunjukkan bahwa guru sudah dapat melakukan kegiatan pembelajaran dengan baik. Pengelolaan kelas yang dilakukan oleh guru dalam siklus III ini jauh lebih baik dibandingkan siklus II. Guru mampu menjelaskan dan mengorganisasikan pembelajaran dengan metode teka-teki silang secara baik. Selain itu guru juga memberikan dorongan kepada 
siswa agar lebih berperan aktif di dalam kelas.

Siswa terlihat lebih berminat dalam mengikuti proses pembelajaran di kelas. Siswa terlihat senang dan sangat bersemangat. Hal tersebut sesuai dengan apa yang diekmukakan oleh Hisyam Zaini, dkk (2012: 71) bahwa metode teka-teki silang dapat digunakan sebagai strategi pembelajaran yang baik dan menyenagkan tanpa menghilangkan asensi belajar yang sedang berlangsung. Selain itu siswa juga lebih berani bertanya. Siswa yang pada siklus sebelumnya terlihat pasif juga sudah mulai aktif. Pada kegiatan akhir, siswa berperan aktif dalam menyimpulkan materi pelajaran bersama dengan guru.

Pada siklus III, minat belajar siswa mengalami peningkatan dari siklus II sebesar $18 \%$ menjadi $88 \%$. Hal tersebut dikarenakan pada III ini guru menerapkan metode pembelajaran Teka-teki silang ditambah dengan gambar. Selain itu, kendala atau kelemahan yang mengakibatkan kegagalan pada siklus II berhasil diatasi pada siklus III. Untuk memperjelas peningkatan minat belajar siswa dalam mata pelajaran IPS, dapat dilihat dalamtabel berikut :

Tabel 7. Peningkatan Minat Belajar Siswa

\begin{tabular}{|c|c|c|c|c|c|c|}
\hline \multirow{2}{*}{ No } & \multirow{2}{*}{ Aspek } & \multirow{2}{*}{ Indikator } & \multicolumn{3}{|c|}{ Siklus } & \multirow{2}{*}{$\begin{array}{c}\text { Kriteria } \\
\text { Keberhasilan }\end{array}$} \\
\hline & & & I & II & III & \\
\hline 1 & Perhatian & $\begin{array}{c}\text { Memperhatikan } \\
\text { guru saat proses } \\
\text { pembelajaran }\end{array}$ & $63 \%$ & $62 \%$ & $87 \%$ & \\
\hline 2 & Ingin Tahu & $\begin{array}{l}\text { Menanyakan materi } \\
\text { yang belum } \\
\text { dimengerti }\end{array}$ & $63 \%$ & $76 \%$ & $86 \%$ & $75 \%$ \\
\hline 3 & Keinginan & $\begin{array}{c}\text { Menjawab dan } \\
\text { merespon petanyaan } \\
\text { guru }\end{array}$ & $64 \%$ & $84 \%$ & $90 \%$ & \\
\hline 4 & $\begin{array}{c}\text { Rasa } \\
\text { Senang }\end{array}$ & $\begin{array}{l}\text { Mengejakan tugas } \\
\text { dari guru }\end{array}$ & $63 \%$ & $61 \%$ & $92 \%$ & \\
\hline & $\begin{array}{r}\text { Rata-rata Pe } \\
\text { Minat } \mathrm{F}\end{array}$ & $\begin{array}{l}\text { ntase Indikator } \\
\text { ajar Siswa }\end{array}$ & $62 \%$ & $70 \%$ & $88 \%$ & \\
\hline
\end{tabular}

Penelitian ini dikatakan berhasil juga apabila $75 \%$ dari siswa kelas VIII A memiliki nilai minimal 70 pada mata pelajaran IPS. Hal ini berdasarkan kurikulum SMP Negeri 28 Banjarmasin mengenai Kriteria Ketuntasan Minimal (KKM) pada mata pelajaran IPS yaitu 70 .

Berikut disajikan tabel mengenai persentase hasil kelompok belajar siswa yang mencapai nilai KKM pada siklus I sampai siklus III.

Tabel 8 Peningkatan Hasil Belajar Kelompok Siswa Siklus I, II, dan III

\begin{tabular}{cccc}
\hline Nilai & Siklus I & Siklus II & iklus III \\
\hline$\leq 70$ & $80 \%$ & $40 \%$ & $20 \%$ \\
\hline$\geq 70$ & $20 \%$ & $60 \%$ & $80 \%$ \\
\hline
\end{tabular}

Beiuasal Kall taveı o llası keıUnpuk verajar siswa siklus I, persentase siswa yang mencapai nilai $\leq 70$ belum mencapai kriteria keberhasilan yaitu $75 \%$ karena baru mencapai $20 \%$. Hal yang sama juga terjadi pada hasil siklus II. Persentase siswa yang mencapai nilai $\leq 70$ belum mencapai kriteria keberhasilan karena baru mencapai $60 \%$ sehingga perlu ditingkatkan lagi pada siklus III. Pada hasil siklus III siswa yang mencapai nilai $\leq 70$ sudah mencapai kriteria keberhasilan yang telah ditentukan bahkan melebihi. Hasil siklus III menunjukkan bahwa besarnya persentase siswa yang telah mencapai nilai $\leq 70$ adalah $80 \%$.

\section{PENUTUP}

Berdasarkan hasil deskripsi dan paparan data dapat dikemukakan bahwa penerapan metode pembelajaran teka-teki silang dapat meningkatkan minat dan hasil belajar siswa dalam pembelajaran IPS dikelas VIII A SMP Negeri 28 Banjarmasin. Peningkatan rata-rata persentase indikator minat belajar siswa setiap siklusnya. Pada siklus I rata- rata persentase indikator minat belajar siswa adalah 62\%. Pada siklus II menjadi $70 \%$ atau mengalami peningkatan sebesar 8\%. Pada siklus III mengalami peningkatan sebesar $18 \%$ sehingga menjadi $88 \%$. Hal ini berarti bahwa rata-rata persentase indikator minat belajar siswa telah melampaui kriteria keberhasilan tindakan yang ditetapkan yaitu $75 \%$. Penerapan metode pembelajaran teka-teki silang dapat meningkatkan hasil belajar siswa. Persentase siswa yang mencapai nilai KKM pada siklus I sebesar $20 \%$ meningkat menjadi $60 \%$ pada siklus II. Selanjutnya masih mengalami peningkatan menjadi $80 \%$ pada siklus III. Hal ini berarti bahwa jumlah 
siswa yang mencapai nilai KKM (70) telah melampaui kriteria keberhasilan yang ditetapkan yaitu $75 \%$.

\section{DAFTAR PUSTAKA}

Agus Sujanto. (2004). Psikologi Umum. Jakarta: PT. Rineka Cipta

Agus Suprijono. (2012). Cooperative Learning: Teori \& Aplikasi PAIKEM. Yogyakarta: Pustaka Pelajar.

Djaali. (2007). Psikologi Pendidikan. Jakarta: PT. Bumi Aksara Djamarah, (2008). Psikologi Belajar. Jakarta: PT. Rineka Cipta.

Mukminan. (2003). Pembelajaran Tuntas (Mastery Learning). Jakarta: Direktorat Pendidikan Lanjut Pertama. Hisyam Zaini, dkk. (2008). Strategi pembelajaran aktif, Yogyakarta: pustaka insani madani

Isjoni. (2010). Pembelajaran Kooperatif. Yogyakarta: Pustaka Pelajar. Lie, Anita (2008). Cooperative Learning, Grasindo: Jakarta

Oemar Hamalik. (2010). Kurikulum dan Pembelajaran. Jakarta: Bumi Aksara. Sardiman. (2009). Interaksi dan Motivasi Belajar Mengajar. Jakarta: Rajawali Pers.

Sugiyono. (2008). Metode Penelitian Kuantitatif, Kualitatif dan $R \& D$. Bandung: Alfabeta.

Zainal Aqib. 2009. Penelitian Tindakan Kelas. Bandung: CV. Yrama Widya. 